\title{
How the Disappearance of Unionized Jobs Obliterated an Emergent Black Middle Class
}

\author{
William Lazonick, Philip Moss, and Joshua Weitz *
}

\author{
Working Paper No. 125
}

June $15^{\text {th }}, 2020$

\begin{abstract}
In this introduction to our project, "Fifty Years After: Black Employment in the United States Under the Equal Employment Opportunity Commission," we outline the socioeconomic forces behind the promising rise and disastrous fall of an African American blue-collar middle class. During the 1960s and 1970s, blacks with no more than high-school educations gained significant access to well-paid unionized employment opportunities, epitomized by semi-skilled operative jobs in the automobile industry, to which they previously had limited access. Anti-discrimination laws under Title VII of the 1964 Civil Rights Act with oversight by the Equal Employment Opportunity Commission supported this upward mobility for blacks in the context of a growing demand for blue-collar labor. From the late 1970s, however, the impact of global competition and the offshoring of manufacturing combined with the financialization of the corporation to decimate these stable and well-paid blue-collar jobs. Under the seniority provisions of the now beleaguered industrial unions, blacks tended to be last hired and first fired. As U.S.-based blue-collar jobs were permanently lost, U.S. business corporations and government agencies failed to make sufficient investments in the education and skills of the U.S. labor force to usher in a new era of upward socioeconomic mobility. This organizational failure left blacks most vulnerable to downward mobility. Instead of retaining corporate profits and reinvesting in the productive capabilities of
\end{abstract}

\footnotetext{
${ }^{*}$ William Lazonick is professor of economics emeritus, University of Massachusetts, and president of the Academic-Industry Research Network; Philip Moss is professor of economics emeritus, University of Massachusetts, and a research associate at the Academic-Industry Research Network; Joshua Weitz is a PhD candidate in political science at Brown University and a research associate at the Academic-Industry Research Network.
} 
employees, major business corporations became increasingly focused on downsizing their labor forces and distributing profits to shareholders in the form of cash dividends and stock buybacks. Legitimizing massive distributions to shareholders was the flawed and pernicious ideology that a company should be run to "maximize shareholder value." As the U.S. economy transitioned from the Old Economy business model, characterized by a career with one company, to the New Economy business model, characterized by interfirm labor mobility, advanced education and social networks became increasingly important for building careers in well-paid white-collar occupations. Along with non-white Hispanics, blacks found themselves at a distinct disadvantage relative to whites and Asians in accessing these New Economy middle-class employment opportunities. Eventually, the downward socioeconomic mobility experienced by blacks would also extend to devastating loss of well-paid and stable employment for whites who lacked the higher education now needed to enter the American middle class. By the twenty-first century, general downward mobility had become a defining characteristic of American society, irrespective of race, ethnicity, or gender. Since the 1980s, the enemy of equal employment opportunity through upward socioeconomic mobility has been the pervasive and entrenched corporate-governance ideology and practice of maximizing shareholder value (MSV). For most Americans, of whatever race, ethnicity, and gender, MSV is the not-so-invisible hand that has a chokehold on the emergence of the stable and well-paid employment opportunities that are essential for sustainable prosperity.

\section{https://doi.org/10.36687/inetwp125}

This INET working paper is the introductory chapter to a forthcoming book by William Lazonick, Philip Moss, and Joshua Weitz, Fifty Years After: Black Employment in the United States Under the Equal Employment Opportunity Commission. We will also be publishing the five other chapters of the book manuscript as INET working papers:

- Employment and Earnings of Africa Americans, Fifty Years After: Progress?

- Employment Mobility and the Emergence of the Black Middle Class, 1890-1980

- The Unmaking of the Black Middle Class

- Black Exclusion from High-Paid Employment in the New Economy

- What Comes After Fifty Years After?

Funded by the Institute for New Economic Thinking, the "Fifty Years After" project was launched in early 2016. The authors welcome comments on these working papers, which will undergo revision prior to finalizing the book manuscript. Meanwhile, we thank Thomas Ferguson, Louis Ferleger, and Ken Jacobson for comments on this essay and the forthcoming INET working papers listed above.

JEL Codes: D2, D3, G3, J0, L2, L6, N8, O3, P1

Keywords: African American, employment relations, equal employment opportunity, unions, blue-collar, socioeconomic mobility, corporate governance, shareholder value, retain-andreinvest, downsize-and-distribute, discrimination, economic inequality 


\section{The American middle class}

The American working class is in trouble. Taken as a whole, it was more downwardly than upwardly mobile, even in "normal" times, before the devastation of the coronavirus pandemic. ${ }^{1}$ For lack of employment opportunities that can offer productivity-enhancing careers, increasing proportions of the U.S. labor force, even those with college educations, have been pushed into low-productivity, low-paid jobs. Labor-force participation has been declining, while substance abuse, both legal and illegal, has been on the rise. In recent years, the life-expectancy of white males without college educations has shortened, repeating what happened to black males at the end of the 1980s. Meanwhile, in the world's largest economy, which still has one of the highest per capita incomes in the world, the income distribution has become highly skewed, with almost all of the income gains during the decade after the Great Recession going to the very richest households. ${ }^{2}$ With the juxtaposition in April and May 2020 of booming U.S. stock markets and tens of millions of Americans joining the ranks of the unemployed, it is virtually certain that the Covid-19 crisis is making extreme economic inequality even worse.

In an essay, "The Equal Employment Opportunity Omission," that we presented in November 2016 at a conference on the economics of race, organized by the Institute for New Economic Thinking, we laid out a perspective for understanding the ongoing disappearance of the U.S. middle class since the $1980 \mathrm{~s}^{3}{ }^{3}$ We argue that, to understand the decline of the U.S. middle class over the past four decades, one must begin with an explanation of the rise of the U.S. middle class in the three to four decades following World War II. The appearance of a high-school-educated middle class in the United States in the post-war decades resulted from blue-collar employment in what, in retrospect, we call the "Old Economy business model" (OEBM). ${ }^{4}$

The equal employment opportunity "omission" is the assumption that prevailed in the mid-1960s, when the Equal Employment Opportunity Commission was created, that the leading U.S. business corporations would offer most members of their labor forces the stability of employment and the increases in real incomes that constitute economic foundations for middle-class status. Under OEBM, the major industrial corporations that dominated the U.S. economy in terms of revenues,

\footnotetext{
${ }^{1}$ Raj Chetty, David Grusky, Maximilian Hell, Nathaniel Hendren, Robert Manduca, and Jimmy Narang, "The Fading American Dream: Trends in Absolute Income Mobility Since 1940," Science, 356, 6336, 2017: 398-406, at https://opportunityinsights.org/paper/the-fading-american-dream/.

${ }^{2}$ William Lazonick, Philip Moss, and Joshua Weitz, "Employment and Earnings of African Americans, Fifty Years After: Progress?" Institute for New Economic Thinking Working Paper, forthcoming.

${ }^{3}$ William Lazonick, Philip Moss, and Joshua Weitz, "The Equal Employment Opportunity Omission," Institute for New Economic Thinking Working Paper No. 53, December 5, 2016, at https://www.ineteconomics.org/research/research-papers/the-equal-employment-opportunity-omission. This perspective builds on William Lazonick, "Labor in the Twenty-First Century: The Top $0.1 \%$ and the Disappearing Middle Class," in Christian E. Weller, ed., Inequality, Uncertainty, and Opportunity: The Varied and Growing Role of Finance in Labor Relations, Cornell University Press, 2015: 143-192; William Lazonick, Philip Moss, Hal Salzman, and Öner Tulum "Skill Development and Sustainable Prosperity: Collective and Cumulative Careers versus Skill-Biased Technical Change," Institute for New Economic Thinking Working Group on the Political Economy of Distribution Working Paper No. 7, December 2014, at https://ineteconomics.org/ideaspapers/research-papers/skill-development-and-sustainable-prosperity-cumulative-and-collective-careers-versusskill-biased-technical-change.

${ }^{4}$ William Lazonick, Sustainable Prosperity in the New Economy? Business Organization and High-Tech Employment in the United States, Upjohn Institute for Employment Research, 2009, ch. 3; William Lazonick, "The New Economy Business Model and the Crisis of US Capitalism," Capitalism and Society, 4, 2, 2009: article 4.
} 
profits, and employment offered both male blue-collar and male white-collar workers realistic expectations of a career with one company (CWOC), including company-provided medical coverage and a defined-benefit pension in retirement. CWOC gave tens of millions of American workers employment stability, rising real incomes, and the possibility of intergenerational upward mobility. But, under OEBM, CWOC was mainly a white man's world. With the establishment of the Equal Employment Opportunity Commission in 1965 to enforce the laws against workplace discrimination in the Civil Rights Act of 1964, African Americans gained an important source of legal support to enable them to access "the American Dream," especially in unionized blue-collar employment.

White-collar workers generally had more education and higher annual earnings than blue-collar workers. In the immediate post-World War II decades, established businesses offered CWOCs to male white-collar workers, an increasing proportion of whom had at least college degrees. Once a company trained these employees, it wanted to retain them. The promise of a CWOC was realistic because of the size and growth of major companies in these decades; the 20 largest industrial employers in the United States employed a total of 3.1 million people worldwide in 1957, rising to 4.0 million for the same 20 companies in 1977..$^{5}$ These large companies set the standards for employment stability and income equity in the U.S. economy as a whole.

The prospects of promotion up the corporate hierarchy of an established company served as highpowered incentives for white-collar employees to devote their skills and efforts to enable the company to generate the high-quality, low-cost goods and services that could give it a sustained competitive advantage on product markets. The resultant profits were shared with CWOC employees in the form of higher earnings, increased employment stability, enhanced career opportunity, and superior benefits packages. These white-collar employees increased the numbers of the well-educated, experienced, and well-paid upper middle class.

Under OEBM, blue-collar workers, who typically had no more than high-school educations, also gained access to CWOCs, particularly in mass-production industries such as automobiles, electronics, steel, and tires that were dominated by large firms. Building on the legal foundation of the National Labor Relations Act of 1935, over the next two decades the Congress of Industrial Organizations (CIO) coordinated organizing efforts of mass-production unions to secure collective-bargaining certification with the major companies in these industries.

Figure 1 on union membership and union density (the percent of the civilian labor force that was unionized) from 1930 through 2019 provides indicators of the success of these organizing drives. Unions members as a percent of the non-agricultural labor force peaked at 35.5 percent in 1945, while the total number of union members reached its highest level of 22.2 million in 1975. Since the mid-1970s, the percentage of the labor force in unions has persistently declined, while from the early 1980s union membership has eroded dramatically.

\footnotetext{
${ }^{5}$ William Lazonick, "Corporate Restructuring” in Stephen Ackroyd, Rose Batt, Paul Thompson, and Pamela Tolbert, eds., The Oxford Handbook of Work and Organization, Oxford University Press, 2004: 577-601, cited at p. 585. Assuming that in each year 75 percent of these employees were based in the United States, these 20 companies alone would have employed 3.4 percent of the U.S. civilian labor force in 1957 and 3.0 percent in 1977.
} 
Figure 1.1: Union membership and union density in the United States, 1930-2019

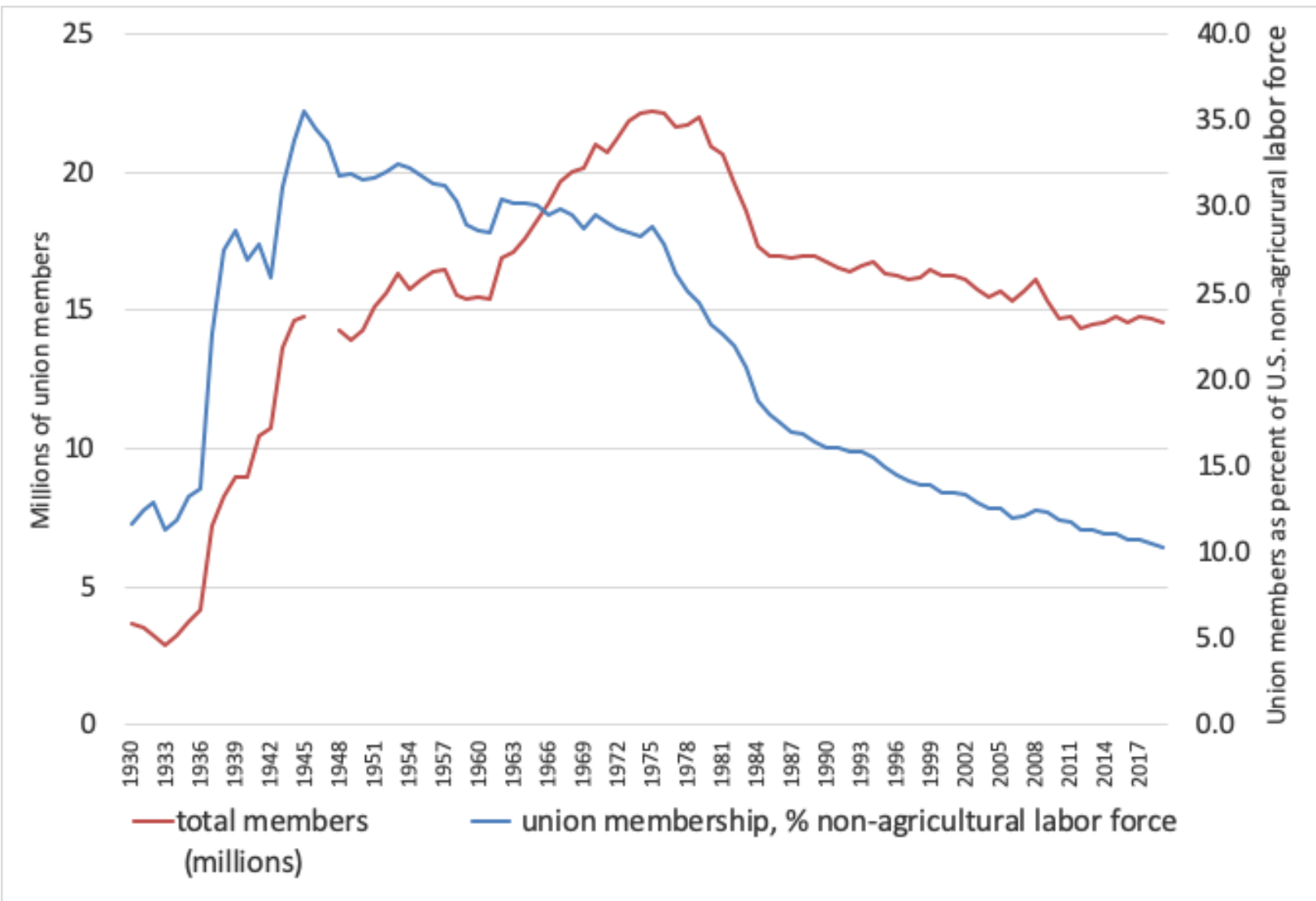

Sources: For 1930-1970, U..S. Census Bureau, Historical Statistics of the United States from Colonial Times to 1970, U.S. Government Printing Office, 1970, p. 178; for 1971-1982, U.S. Census Bureau, "Labor Union and Employee Association Membership," Statistical Abstract of the United States, various issues; for 1983-2019, U.S. Bureau of Labor Statistics, "Databases, Tables \& Calculators by Subject," at https://data.bls.gov/pdq/SurveyOutputServlet. The most recent data are from U.S. Bureau of Labor Statistics, “Union Members Summary,” Economic News Release, January 21, 2020, at http://www.bls.gov/news.release/union2.nr0.htm

The fundamental principle of mass-production unionism in the decades after World War II was the protection of worker seniority, or first hired, last fired. The seniority principle was consistent with employment practices that major mass-production companies had instituted in the non-union era of the 1920s, when leading manufacturing companies had recognized the cost advantages of the continuity of employment of reliable "semi-skilled" operatives working in mass-production factories. ${ }^{6}$ In these capital-intensive workplaces, labor turnover was costly because new employees lacked the habituation to work effort that comes with experience, resulting in reduced throughput and hence lowered scale economies. Green workers were also more likely to inadvertently damage expensive machines and materials.

\footnotetext{
${ }^{6}$ See William Lazonick, Competitive Advantage on the Shop Floor, Harvard University Press, 1990, chs. 7-9
} 
Moreover, a low level of work effort was not always because of inexperience, and damage to machines and materials was not always inadvertent. In the 1910 and 1920s, many major U.S. employers had found that the provision of the stable employment inherent in the seniority principle to a cooperative labor force was an antidote to disgruntled operatives, often possessing substantial experience, who could, and often did, deliberately restrict output, sabotage equipment, and waste materials. ${ }^{7}$ When, from the last half of the 1930s, the new mass-production unions insisted on the seniority principle, major mass producers were already receptive to this type of stable employment relation.

In the late 1940s and 1950s, mass-production unions increased their collective-bargaining leverage, in part by agreeing to limit union power to wage negotiations while eschewing participation in corporate decision-making, including the organization of work on the shop floor. In exchange, corporate management explicitly accepted the seniority principle in adjusting employment to the business cycle, while also including cost-of-living allowances in collective bargains to maintain real wages. As an extension of the seniority principle and as an integral part of collective bargaining, industrial corporations funded defined-benefit pensions based on years of service that the unions regarded as "deferred wages." ${ }^{\circ}$ With industrial expansion in the 1950s and 1960s, middle-class employment opportunities opened for millions of semi-skilled production workers.

With union-bargained hourly wages, blue-collar workers often had their incomes boosted substantially by being eligible for "time-and-a-half" overtime pay under the Fair Labor Standards Act of 1938, from which white-collar workers, as members of "management," tended to be excluded-or, in the language of the Act, "exempt." Compared with white-collar workers, bluecollar workers were more prone to layoffs in slack periods, but many unions provided them with unemployment benefits that supplemented government-run unemployment insurance until they were rehired in the upturn. ${ }^{10}$

Buoyed by collective-bargaining power, blue-collar workers swelled the ranks of the lower middle class. Under OEBM, in the postwar decades, both white-collar and blue-collar workers had income levels, employment stability, as well as health and retirement benefits that provided living standards that placed them in a broad American middle class.

During the prosperous post-World War II decades, the combination of middle-class incomes of blue-collar workers and government investment in the nation's knowledge base created the opportunity for offspring of blue-collar workers to acquire the college educations that were increasingly required to access white-collar employment opportunities. ${ }^{11}$ The federal

7 Ibid.

8 Teresa Ghilarducci, Labor's Capital: The Economics and Politics of Private Pensions, MIT Press, 1992 , p. 35.

9 Jonathan Grossman, "Fair Labor Standards Act of 1938: Maximum Struggle for a Minimum Wage," Monthly Labor Review, 101, 6, 1978: 22-30.

10 John W. Budd and Brian B. McCall, "The Effects of Unions on the Receipt of Unemployment Insurance Benefits," ILR Review, 50, 3, 1997: 478-492.

${ }^{11}$ Matt Hopkins and William Lazonick, "Who Invests in the High-Tech Knowledge Base?” Institute for New Economic Thinking Working Group on the Political Economy of Distribution Working Paper No. 6, September 2014 (revised December 2014), at http://ineteconomics.org/ideas-papers/research-papers/who-invests-in-the-hightech-knowledge-base. 
government's GI Bill aided this upward mobility by subsidizing attendance at college while state governments gave state residents free or low tuition at public universities. But, given the highschool educational credentials required to take advantage of the GI Bill, its benefits accrued mostly to whites, and indeed only served to increase the socioeconomic gap between whites and blacks. ${ }^{12}$ In the 1950s, it was mainly white families who experienced this intergenerational upward mobility.

It must be emphasized that CWOC was a white man's world. Under OEBM, companies did not provide women with the expectation of a CWOC because it was assumed that they would drop out of the labor force to raise families, a corporate policy that often took the form of "marriage bars." 13 Through the 1950s and into the 1960s, at large established U.S. corporations, the species of employee who, in his best-selling book of 1956 William H. Whyte called "the organization man," was almost always male, and these organization men were almost always white. ${ }^{14}$ For example, it was not until 1964, just after the signing of the U.S. Civil Rights Act, that Harvard Business School admitted women to its MBA program. ${ }^{15}$

\section{Blacks gain and then lose access to unionized blue-collar employment}

In the 1960s and 1970s, more limited, yet significant, opportunities for upward mobility through employment opportunity also opened up for blacks. With the intergenerational upward mobility of white workers from blue-collar to white-collar employment accelerating in the 1960s while the demand for blue-collar labor continued to expand, there was a movement of hundreds of thousands of blacks into middle-class blue-collar work in unionized mass-production industries as they gained access to semi-skilled employment from which they had previously been largely excluded. Given union-bargained wages, seniority, and benefits, these semi-skilled unionized jobs were distinctly middle-class employment opportunities, even if at the lower end of that broad socioeconomic category. From 1965, the Equal Employment Opportunity Commission (EEOC), established by Title VII of the Civil Rights Act of 1964, aided this upward mobility of blacks into semi-skilled blue-collar jobs. Now there was the possibility that, as had happened with whites, a large proportion of the next generation of blacks, and especially the sons and daughters of the new black blue-collar middle class, would attain college educations and ascend into CWOC whitecollar employment opportunities.

As a mass phenomenon, however, the expectation that blacks would now have their turn to use higher education for the intergenerational ascension up the corporate occupational hierarchy did not come to fruition. Instead, from the late 1970s, unionized semi-skilled blue-collar employment entered into a long-run decline in the United States, with blacks, having been last hired, generally being the first to lose these middle-class jobs. As this decline continued over the ensuing decades,

\footnotetext{
${ }^{12}$ Sarah Turner and John Bound, "Closing the Gap or Widening the Divide: The Effects of the G.I. Bill and World War II on the Educational Outcomes of Black Americans," Journal of Economic History, 63, 1, 2003: 145-177. Richard Rothstein, The Color of Law: A Forgotten History of How Our Government Segregated America, Liveright Publishing, 2016: 69-75; Ira Katznelson, When Affirmative Action was White: An Untold History of Racial Inequality in Twentieth-Century America, W.W. Norton, 2005, ch. 5.

${ }^{13}$ Claudia Goldin, “Marriage Bars: Discrimination Against Married Women Workers, 1920's to 1950's,” NBER Working Paper No. 2747, October 1988.

${ }^{14}$ William H. Whyte, The Organization Man, Simon \& Schuster, 1956.

${ }^{15}$ Elizabeth M. Fowler, "Harvard Business School goes coed with Ivy aplomb," New York Times, February 21, 1964.
} 
high-school-educated whites also found it more difficult to achieve a middle-class standard of living and had less funds available to support the educational investments that their offspring would need to move into white-collar jobs.

Moreover, in the 1980s, at just the time when blue-collar black families should have been positioned to make use of low-cost public higher education as a foundation for intergenerational upward mobility, the public commitment to low-cost higher education eroded, manifested by rising tuitions and high-cost student loans. ${ }^{16}$ With both the educational and employment rugs pulled out from under them, intergenerational downward mobility has become the norm for blacks and whites, and almost all other members of the U.S. labor force who lack college educations. ${ }^{17}$

Currently, this downward mobility of the less educated members of the U.S. working class persists, with economic consequences that are tragic and political consequences that are disastrous. Since the astonishing ascendancy of Donald Trump to the position as "leader of the free world," there has been intense interest in the desperate straits of the badly-educated, drug-addicted white workers who gave this con-man his critical margin of support. ${ }^{18}$ But the origins of this downward mobility date back to the massive plant closings of the 1980s. And back then, as we show in the "Fifty Years After" study, the downsizing was meted out to blacks first and faster, with even more dire socioeconomic consequences than for blue-collar whites.

Why have blue-collar jobs for American workers disappeared? A common response is "automation." There is no doubt that, over the decades, the digital revolution has transformed the American factory, permitting given levels of output with far fewer production workers. Yet in the 1980s, when the permanent decline in U.S. blue-collar employment took hold, the cause was not the automation of U.S. factories. Rather competition from the Japanese was the prime reason for the loss of unionized blue-collar jobs in industries such as automobiles, electronics, steel, and tires. With a combination of shop-floor skill and automated machinery, Japanese companies outcompeted the much-vaunted U.S. system of mass production. The nature of the response by U.S. corporations that faced competition from Japanese companies greatly narrowed the

${ }^{16}$ College Board, “Trends in College Pricing 2019” p. 12, at https://research.collegeboard.org/pdf/trends-collegepricing-2019-full-report.pdf: In 2019 dollars, average tuition and fees rose from $\$ 3,510$ in 1989-90 to $\$ 10,440$ in 2019-20. On student loans, see College Board, “Trends in Student Aid 2019," p. 15, at

https://research.collegeboard.org/pdf/trends-student-aid-2019-full-report.pdf: In 2018 dollars, all types of student loans increased from $\$ 52.7$ billion to $\$ 106.2$ billion. But in 1998-99 48 percent of the total were subsidized federal loans and 32 percent were unsubsidized federal loans, whereas in 2018-19 these federal-loan figures were 19 percent subsidized and 46 percent unsubsidized.

${ }^{17}$ Raj Chetty, Nathaniel Hendren, Maggie R. Jones, and Sonya R, Porter, "Race and Economic Opportunity in the United States: An Intergenerational Perspective," Opportunity Insights Working Paper, March 2018, at https://opportunityinsights.org/paper/race//. See also Emily Badger, Claire Cain Miller, Adam Pearce, and Kevin Quealy, "Extensive data shows punishing reach of racism for black boys," New York Times, March 19, 2018, at https://www.nytimes.com/interactive/2018/03/19/upshot/race-class-white-and-black-men.html.

${ }^{18}$ Shannon M. Monnat and David L. Brown, "More Than a Rural Revolt: Landscapes of Despair and the 2016 Presidential Election," Journal of Rural Studies, 55, 2017, pp. 227-236; Thomas Ferguson, Benjamin Page, Jacob Rothschild, Arturo Chang, and Jie Chen, "The Economic and Social Roots of Populist Rebellion: Support for Donald Trump in 2016," Institute for New Economic Thinking Working Paper No. 83, October 2018, at https://www.ineteconomics.org/uploads/papers/WP 83-Ferguson-et-al.pdf; Usama Bilal, Emily A. Knapp, and Richard S. Cooper, "Swing Voting in the 2016 Presidential Election in Counties Where Midlife Mortality Has Been Rising in White Non-Hispanic Americans," Social Science \& Medicine, 197(C), 2018: 33-38. 
opportunity for blacks without a college degree to find employment opportunities that could keep them in, or elevate them into, the middle class, even more so than for their white counterparts.

In the 1970s, when Japanese competition began to be felt, it appeared as if low wages, long work hours, and a weak currency were enabling the Japanese to outcompete Americans in industries such as automobiles, consumer electronics, steel, machine tools, and memory chips - industries in which U.S. companies had been the world leaders. Yet, as Western experts went to Japan and learned about the productive advantages of the Japanese system, it became evident that the foundation of Japanese competitive advantage was investment in the skills of not only engineers within the management structure but also production workers on the shop floor. Incentivized by the security of "lifetime" employment, engineers, managers, and production workers integrated their skills and efforts to create an unsurpassed capability for collective and cumulative learning. The results were the higher-quality, lower-cost products that gave many Japanese companies a sustained advantage in global competition. ${ }^{19}$

In the early 1980s, as it became clear that Japanese industry had achieved sustained competitive advantage in this range of industries, the narrative from U.S. academics shifted to the purported role of Japan's developmental state, and in particular support from the Ministry of International Trade and Industry (MITI), as the prime source of the nation's industrial success ${ }^{20}$ In historical perspective, however, in terms of government support for a technology knowledge base, the United States had a far more formidable developmental state than Japan, and indeed through international technology transfer the United States in effect served as Japan's developmental state. ${ }^{21}$ Far more important than MITI as an arm of the Japanese developmental state in the post-World War II decades was the financing of the high-speed growth of industrial corporations through "main-bank lending" supported by the Bank of Japan combined with the Ministry of Finance's Fiscal Investment and Loan Program. ${ }^{22}$

Ultimately, it was the capability of Japanese mass producers to outcompete their U.S. rivals in the generation of high-quality, low-cost products that accounts for the strength of the Japanese challenge to U.S. business. With secure jobs and accumulated work experience, Japanese bluecollar workers cooperated with managers and engineers in automating the more routine massproduction jobs. In the process, the Japanese became world leaders in factory automation. ${ }^{23}$ In keeping with American practice, the U.S. companies neglected to invest in the productive

${ }^{19}$ See William Lazonick, "Organizational Learning and International Competition,” in Jonathan Michie and John Grieve Smith, eds., Globalization, Growth, and Governance, Oxford University Press, 1998: 204-238.

${ }^{20}$ The most influential proponent of this perspective was Chalmers Johnson, MITI and the Japanese Miracle: The Growth of Industrial Policy, 1925-1975, Stanford University Press, 1982.

${ }^{21}$ See William Lazonick, "The Japanese Economy and Corporate Reform: What Path to Sustainable Prosperity?" Industrial and Corporate Change, 8, 4, 1999: 607-633; Hopkins and Lazonick, "Who Invests in the High-Tech Knowledge Base?"

${ }^{22}$ William Lazonick, "The Institutional Triad and Japanese Development," [published in Japanese translation] in Glenn Hook and Akira Kudo, eds., The Contemporary Japanese Enterprise, Yukikaku Publishing, 2005, Volume 1: 55-82; William Lazonick, "Innovative Business Models and Varieties of Capitalism: Financialization of the US Corporation," Business History Review, 84, 4, 2010: 675-702.

${ }^{23}$ See, for example, John Hartley, ed., Flexible Automation in Japan, Springer-Verlag Berlin Heidelberg, 1984; Robert E. Kemelhor, "Manufacturing Automation in Japan: A Trip Report and Observations," Johns Hopkins APL Technical Digest, 8, 2, 1987: 272-277, at http://techdigest.jhuapl.edu/views/pdfs/V08 N2 1987/V8 N2 1987 Kemelhor.pdf; 
capabilities of shop-floor workers, leaving U.S. mass production vulnerable to competitors - not only from Japan but also, over time, from South Korea, Taiwan, Malaysia, Thailand, and Chinanations in which companies have shown themselves to be far more able and willing than U.S. companies to undertake integrated investments in workers' skills and automated production processes. Indeed, to this day, while major Japanese mass producers maintain the system of permanent employment that gives them an incentive to train and retain blue-collar workers, they also lead the world in both robotics innovation and robotics utilization. ${ }^{24}$

In the early 1980s, Japan began exporting not only its high-quality, low-cost products but also its management methods, as manufacturers around the world learned about quality circles, continuous improvement, single-digit setup, and just-in-time inventory, among other productivity-improving practices that depend on the integration of the skills and efforts of operatives and engineers. Then from the mid-1980s Japan began "exporting" its production facilities. With wages rising rapidly in Japan, the Japanese yen strengthening, and Japanese car exports to the United States limited by voluntary export restraints, Japanese automobile producers established manufacturing facilities in the United States. With the exception of Mazda, which built a plant in Flat Rock, Michigan, near Detroit, the Japanese car companies avoided the traditional urban areas in which U.S. producers employed most of their workers, and, in their greenfield rural non-union plants, the Japanese avoided employing blacks..$^{25}$ Thus, in a key mass-production industry in the 1980s, blacks lost their jobs in unionized plants while they were largely excluded from participating in the new middleclass blue-collar employment opportunities being offered by the Japanese transplants.

Given the superior productivity of the Japanese in cars, electronics, steel, and tires, U.S. mass producers sought to compete by cutting wages and laying off employees. From the early 1980s, permanent plant closings became common and continued at a high rate throughout the decade. In search of lower labor costs, U.S. companies increasingly offshored routine production processes to low-wage areas of the world, with a focus on Latin America, and especially Mexico, for consumer-durable manufacturing and Southeast Asia for the burgeoning microelectronics industry. In microelectronics (i.e., semiconductor chips, computers, and eventually cellphones), U.S. companies engaged in design, development, and marketing activities in the United Statesemploying mainly college-educated white-collar workers-with the blue-collar work of manufacturing being done in Malaysia, Thailand, and, increasingly, China. ${ }^{26}$

\section{From retain-and-reinvest to downsize-and-distribute}

As Lazonick has analyzed in detail, in the 1980s and 1990s, with the widespread shuttering of plants and the offshoring of jobs, the resource-allocation strategies of many major Old Economy

\footnotetext{
${ }^{24}$ Ulrike Schaede, Choose and Focus: Japanese Business Strategies for the $21^{\text {st }}$ Century, Cornell University Press, 2008; William Lazonick, Sustainable Prosperity in the New Economy? Business Organization and High-Tech Employment in the United States, W. E. Upjohn Institute for Employment Research, 2009; William Lazonick, Yu Zhou, and Yifei Sun, "Introduction: China as an Innovation Nation," in Yu Zhou, William Lazonick, and Yifei Sun, eds., China as an Innovation Nation, Oxford University Press, 2016; International Federation of Robotics, "Robots: Japan delivers 52 percent of global supply," IFR Press Release, November 23, 2017.

${ }^{25}$ See Robert E. Cole and Donald R. Deskins, Jr., "Racial Factors in Site Locations and Employment Patterns of Japanese Auto Firms in America," California Management Review, 31, 1, 1988: 9-22; William Lazonick, Philip Moss, and Joshua Weitz, "The Unmaking of the Black Middle Class," Institute for New Economic Thinking Working Paper, forthcoming.

${ }^{26}$ Lazonick, Sustainable Prosperity in the New Economy? ch. 5.
} 
U.S. business corporations transformed from "retain-and-reinvest" to "downsize-and-distribute."27 In the post-World War II decades, U.S. corporations tended to retain a large portion of corporate profits for investment in the corporation's productive capabilities, both physical and human, as well as to reward employees for their past contributions to current profits in the form of higher wages, superior benefits, and secure employment. But, from the 1980s there was a growing tendency of U.S. corporations to downsize the U.S. labor force and distribute corporate profits to shareholders in the form of cash dividends and stock buybacks. Indeed, in many cases, companies have distributed more than 100 percent of their profits to shareholders for years on end, funding these distributions by taking on debt, selling assets, laying off workers, pressing down wages and benefits, and eating into cash reserves. ${ }^{28}$

From a retain-and-reinvest perspective, dividends are a legitimate way in which a company can provide households as savers with a yield on the shares that they choose to hold. But, if the company is concerned with maintaining and extending its competitive capabilities and rewarding the value-creating contributions of its employees, dividends should only be paid after the company has shared the gains with employees and invested in the productive capabilities that can ensure both a large extent of the market for existing products and the generation of new high-quality, lowcost products. These investments include the value-creating capabilities of the company's labor force. And the company needs to use a portion of its current profits to reward employees in terms of pay, security, and benefits for their value-creating contributions to those profits that they made in the past.

In contrast, the distribution of corporate cash to shareholders in the form of stock buybacks done as open-market repurchases is accomplished by a temporary boost to the company's stock price that creates opportunities for sharesellers to time their stock sales to reap gains. Prominent among these sharesellers have been senior corporate executives who make the decisions to do stock buybacks and who can boost their own stock-based pay through the timing of the exercise of stock options and the vesting of stock awards to capture the gains from the very stock prices that buybacks have manipulated. ${ }^{29}$ Joining senior executives in this value-extracting activity are hedge-

${ }^{27}$ William Lazonick and Mary O'Sullivan, "Maximizing Shareholder Value: A New Ideology for Corporate Governance," Economy and Society, 29, 1, 2000: 13-35; Lazonick, "Labor in the Twenty-First Century"; William Lazonick, "Stock Buybacks: From Retain-and-Reinvest to Downsize-and-Distribute," Center for Effective Public Management, Brookings Institution, April 2015, pp. 10-11, at http://www.brookings.edu/research/papers/2015/04/17-stock-buybacks-lazonick.

${ }^{28}$ William Lazonick, "Profits Without Prosperity: Stock Buybacks Manipulate the Market and Leave Most Americans Worse Off," Harvard Business Review, September 2014, 46-55 Lazonick, "Stock Buybacks"; William Lazonick and Jang-Sup Shin, Predatory Value Extraction: How the Looting of the Business Corporation Became the US Norm and How Sustainable Prosperity Can Be Restored, Oxford University Press, 2020; William Lazonick, Mustafa Erdem Sakinç, and Matt Hopkins, "Why Stock Buybacks Are Dangerous for the Economy," Harvard Business Review, January 7, 2020, at https://hbr.org/2020/01/why-stock-buybacks-are-dangerous-for-theeconomy?ab=hero-subleft-2.

${ }^{29}$ Matt Hopkins and William Lazonick, "The Mismeasure of Mammon: Uses and Abuses of Executive Pay Data," Institute for New Economic Thinking Working Paper No. 49, August 29, 2016, at https://www.ineteconomics.org/ideas-papers/research-papers/the-mismeasure-of-mammon-uses-and-abuses-ofexecutive-pay-data. See also William Lazonick, "The Value-Extracting CEO: How Executive Stock-Based Pay Undermines Investment in Productive Capabilities," Institute for New Economic Thinking Working Paper No. 54, December 4, 2016, at https:/www.ineteconomics.org/research/research-papers/the-value-extracting-ceo-howexecutive-stock-based-pay-undermines-investment-in-productive-capabilities; Lenore Palladino, "Do Corporate 
fund managers and investment bankers who are in the business of reaping gains from the stock market through the timing of their stock trades. ${ }^{30}$

Within the corporation, however, it is not only senior corporate executives and board members who may be incentivized by stock-based pay. From the 1960s, but with a huge surge in the 1980s and 1990s, high-tech startups, operating under the "New Economy business model" (NEBM), extended stock options and stock awards to a broad base of professional, technical, and administrative employees in order to lure them away from CWOC employment with established Old Economy firms. ${ }^{31}$ As startups, these New Economy companies could not realistically offer CWOCs to these employees. But they could offer them the potential of a pay bonanza if and when the startup did an initial public offering (IPO) on the NASDAQ electronic stock exchange, or when the startup was sold to a publicly listed company. ${ }^{32}$

After an IPO, shares that employees acquired by exercising stock options at low prices, set when the company was still privately held, could now be sold for substantial gains on the public stock market. Alternatively, employees could reap these stock-based gains when the private company for which they worked was acquired by a company that was already publicly listed. The collegeeducated white-collar workers who joined these startups in the 1980s and 1990s often accepted lower salaries and benefits than they could have received at Old Economy companies with a view to the potential, but uncertain, gains from stock-based pay. These New Economy employees in effect gave up Old Economy CWOCs for the possibility - or really the gamble - of a relatively quick and often very lucrative payday by being with the right New Economy company at the right time.

As the most successful of these New Economy companies such as Intel, Microsoft, and Cisco grew to employ tens of thousands of workers, they did not adopt the Old Economy employment practice of CWOCs. In the information-and-communication-technology (ICT) industries, the shift from OEBM to NEBM was also a shift from proprietary technology systems that placed a high value on the firm-specific experience and insights of CWOC employees to open-technology systems that placed a high value on younger employees with the latest digital skills, often obtained through

Insiders Use Stock Buybacks for Personal Gain?" International Review of Applied Economics, 34, 2, 2020: 153174, at https://www.tandfonline.com/doi/abs/10.1080/02692171.2019.1707787.

${ }^{30}$ Lazonick and Shin, Predatory Value-Extraction.

${ }^{31}$ Lazonick, Sustainable Prosperity in the New Economy? chs. 2 and 3; Lazonick, "The New Economy Business Model"; William Lazonick, "The Functions of the Stock Market and the Fallacies of Shareholder Value," Institute for New Economic Thinking Working Paper No. 58, July 20, 2017, at https://www.ineteconomics.org/research/research-papers/the-functions-of-the-stock-market-and-the-fallacies-ofshareholder-value.

${ }^{32}$ NASDAQ had been launched in 1971 by the National Association of Security Dealers to internetwork their members to provide instantaneous automated quotations of the stock prices of the publicly listed companies traded "over-thecounter" by security dealers around the nation. In contrast to the Old Economy New York Stock Exchange, NASDAQ had lax listing requirements in terms of market capitalization and a profit record, enabling startups to list on this highly speculative market within a few years from founding. The possibility that NASDAQ created for a quick and profitable "exit" of a private-equity investment induced venture capital to fund startups, and 1973 saw the emergence out of Silicon Valley of the National Venture Capital Association as a national lobby for lower capital-gains tax rates, rules to enable pension-fund investment in venture-capital funds, and stock-market liquidity. 
experience at other companies. Instead of adopting CWOCs, New Economy companies such as Intel, Microsoft and Cisco continued to grant stock options to tens of thousands of employees.

Increasingly, leading Old Economy companies-among them AT\&T (and after 1996 Lucent Technologies and NCR), Hewlett-Packard (HP), International Business Machines (IBM), Motorola, Texas Instruments, and Xerox in ICT, and Johnson \& Johnson, Merck, Pfizer, Eli Lilly, and Bristol-Myers Squibb in pharmaceuticals - found that they would train young employees but then be unable to retain them in competition with NEBM companies, thus eroding the CWOC rationale. Especially once IBM, the iconic CWOC firm, had made the transition from OEBM to NEBM in the early 1990 s - cutting employment from 374,000 in 1990 to 220,000 in 1994-one Old Economy company after another followed suit in a process that we call "marketization" of the employment relation, attracting and rewarding a broader base of employees with stock options, in addition to salaries, and putting an end to the CWOC employment norm.

A characteristic feature of many New Economy companies was a focus on development, design, and marketing of products, while outsourcing manufacturing activities, including the production of components and the assembly of final products to specialized contract manufacturers. For example, Cisco grew from 250 employees in 1990 to 34,000 employees in 2000 to become the world's leading supplier of Internet enterprise-communication equipment, without doing any manufacturing in its own facilities. As Old Economy companies made the transition from OEBM to NEBM in the 1990s, they tended to adopt this feature of NEBM, divesting their manufacturing plants to independent contractors. In addition, from 1993, once the U.S. government made the Internet available for commercial purposes, Cisco was able to expand sales rapidly by relying on value-added resellers to interact with buyers rather than investing in a direct-sales force. ${ }^{33}$ Whereas OEBM relied on vertical integration, NEBM emphasized vertical specialization, with the layers connected by national and, increasingly, global value chains.

Initially the contract manufacturers that over the 1990s came to characterize the ICT industries, with Celestica (formerly IBM Canada), Solectron, Sanmina-SCI, Flextronics, and Jabil Circuit as the leaders, operated their plants in North America, but increasingly they relocated them to nations in East and Southeast Asia. Thus, as Lazonick has detailed, the transition from OEBM entailed a combination of rationalization (including plant closings), globalization (including offshoring), and marketization (including the demise of the CWOC norm, epitomized by IBM), all of which worked against the possibility that high-school-educated Americans would secure and hold jobs that would provide the high wages, stability, and benefits that afforded them entry into the middle class. ${ }^{34}$

One needs to be aware of this history of the transformation of U.S. employment relations to understand why and how high-school-educated blacks experienced only fleeting upward socioeconomic mobility in the 1960s and 1970s. By the 1980s and 1990s, the previous movement of blacks into unionized blue-collar work transformed into downward socioeconomic mobility. As stated previously, in throwing blue-collar blacks out of work, the demise of OEBM in the 1980s and 1990s significantly reduced the chances for the offspring of blue-collar blacks to access opportunities to make the intergenerational transition to higher-paid white-collar employment

\footnotetext{
${ }^{33}$ Marie Carpenter and William Lazonick, “Why Isn’t Cisco Huawei?” The Academic-Industry Research Network, in process, June 2020.

${ }^{34}$ Lazonick, Sustainable Prosperity in the New Economy?
} 
requiring a college education - a transition that white families had experienced in earlier decades, when OEBM dominated.

That meant that whites as a group, and especially white males, were better positioned to respond to the demise of OEBM and its CWOC norm in the 1980s and 1990s by building social networks to take advantage of employment opportunities for college-educated personnel under NEBM. But, for blacks as a group, who had not made this intergenerational transition under OEBM as the dominant U.S. business model, the demise of OEBM and the rise of NEBM meant that, even with a college education, immense barriers to building the social networks required for intergenerational upward mobility were in place. ${ }^{35}$

College-educated whites who had built these career-building networks under OEBM with its CWOC norm could draw upon these networks for interfirm career mobility with the rise of NEBM. Particularly within managerial structures, CWOC employment had been a white-male enclave. With the transition to NEBM employment relations, white males continued to dominate as they built new types of social networks in educational institutions, industrial sectors, professional associations, and industrial regions to facilitate the interorganizational mobility needed to build and sustain careers.

Having been largely excluded from the CWOC club that characterized OEBM managerial structures, college-educated blacks, Hispanics, and women were poorly positioned to build these networks with the transition from OEBM to NEBM. Asian men have been much more successful in constructing and using these career-building networks under NEBM because, particularly after the Immigration Act of 1990, large numbers of college educated Asians immigrated to the United States for the purpose of obtaining more advanced STEM (science, technology, engineering, mathematics) degrees. ${ }^{36}$ The result of the lack of social networks (often called "social capital") under NEBM for other groups are, however, clear in the data on the meager representation of blacks, Hispanics, and women in STEM occupations, as we document in a forthcoming working paper. ${ }^{37}$

From the 1980s, the rationalization of outmoded U.S. capacity through plant closings, the globalization of manufacturing through offshoring to low-wage locations, and the marketization of employment relations through the replacement of CWOCs with interfirm mobility for the whitecollar labor force all served to erode the possibilities that high-school-educated Americans would be able to spend their working lives in middle-class employment, as had been the case in the three decades or so after World War II. These changes should not have meant, however, that a generation of high-school-educated Americans had to be downwardly mobile. In collaboration with the U.S. government, U.S. companies could have used the profits from rationalization, globalization, and marketization to invest in upgrading the productive capabilities of their blue-collar workers at home, so that, through higher education and workplace experience, they could engage in productive employments - some of them in the performance of government-funded social services - that could sustain the U.S. middle class.

\footnotetext{
${ }^{35}$ See William Lazonick, Philip Moss, and Joshua Weitz, "Black Exclusion from High-Paid Employment in the New Economy," Institute for New Economic Thinking Working Paper, forthcoming,

${ }^{36}$ Lazonick, Sustainable Prosperity in the New Economy? ch. 5.

${ }^{37}$ Lazonick, Moss, and Weitz, "Black Exclusion from High-Paid Employment." See also Lazonick et al., "Skill Development and Sustainable Prosperity."
} 
Instead, from the 1980s, U.S. companies increasingly justified cutting wages and laying off workers with a new ideology that for the sake of superior economic performance companies should allocate corporate resources to "maximize shareholder value" (MSV). This ideology had few adherents in boardrooms and business schools at the beginning of the 1980s, but had already gained support from conservative economists who opposed the civil-rights and consumer movements that placed new demands on corporate governance and employment in the 1960s and 1970s. ${ }^{38}$ By the end of the 1980s, MSV dominated the thinking of senior corporate executives and their boards of directors as well as MBA and executive-education teaching at U.S. business schools. Rather than upgrade the capabilities of the American worker through new retain-and-reinvest business models, supported by government investment in the knowledge base, MSV ideology, as propounded by "free market" academic economists, legitimized downsize-and-distribute ${ }^{39}$

\section{The erroneous and insidious ideology of maximizing shareholder value}

Based on MSV ideology, academic economists known as agency theorists advised business corporations to "disgorge" their "free" cash flow to shareholders by using stock-based executive pay to align the incentives of corporate executives as "agents" with public shareholders as "principals." 40 The term "disgorge" implies that the cash that has accumulated in a company is being wrongfully withheld from shareholders. In fact, it should support stable and equitable employment, both white-collar and blue-collar, for workers whose skills and efforts helped to generate profits. The term "free" can include cash flow that, instead of being used to reward workers for their value-creating contributions made in the past and to invest in innovative products and processes for the future, can instead be made "free" to be distributed to shareholders by employee layoffs and suppression of wages and benefits. In practice, in the implementation of MSV ideology, agency theory has justified "downsize-and-distribute," characterized by the cutting of labor costs and massive distributions to shareholders in the form of dividends and buybacks. ${ }^{41}$

These distributions to shareholders, and particularly buybacks, bear a major share of the responsibility for concentrating income among the richest $0.1 \%$ of households while undermining investment in middle-class employment opportunities. Research by the Academic-Industry

\footnotetext{
${ }^{38}$ See Milton Friedman, "The social responsibility of business is to increase its profits" New York Times Magazine, September 13, 1970; Michael C. Jensen and William H. Meckling, "Theory of the Firm: Managerial Behavior, Agency Costs, and Ownership Structure," Journal of Financial Economics, 3, 4, 1976: 305-360. For critiques, see William Lazonick, "Innovative Enterprise and Sustainable Prosperity," AIR Working Paper, January 2019, at http://www.theairnet.org/v3/backbone/uploads/2019/03/Lazonick-IESP-20190118.pdf; Joshua Weitz, "'Women, Blacks, Consumers of a Clean Environment': Toward a Political History of Shareholder Value," Paper presented at the Sixty-Fourth Annual Meeting of the New York State Sociological Association, Rochester Institute of Technology, Sept. 30, 2016; William Lazonick and Mustafa Erdem Sakinç, "Make Passengers Safer? Boeing Just Made Shareholders Richer," The American Prospect, May 31, 2019, at https://prospect.org/environment/makepassengers-safer-boeing-just-made-shareholders-richer./; William Lazonick and Matt Hopkins, "How 'Maximizing Shareholder Value' Minimized the Strategic National Stockpile: Government-Business Collaborations, Pandemic Preparedness, and the Ventilator Shortage," The Academic-Industry Research Network, June 2020 (forthcoming).

${ }^{39}$ Lazonick, "Innovative Enterprise and Sustainable Prosperity."

${ }^{40}$ Michael C. Jensen, "Agency Costs of Free Cash Flow, Corporate Finance, and Takeovers," American Economic Review, 76, 2, 1986: 323-329; Michael C. Jensen and Kevin J. Murphy, "Performance Pay and Top Management Incentives" Journal of Political Economy, 98, 2, 1990: 225-264.

${ }^{41}$ Lazonick, "Innovative Enterprise and Sustainable Prosperity."
} 
Research Network for the Institute of New Economic Thinking shows that companies that are intent on "unlocking shareholder value" through buybacks as well as dividends seek to increase the profits from which these distributions can be made through price-gouging, wage-cutting, layoffs, and tax avoidance. ${ }^{42}$ For example, the prime use of the augmented corporate profits from the Republican Tax Cuts and Jobs Act of 2017 was to increase stock buybacks. ${ }^{43}$

Since the mid-1980s, U.S. corporations have spent trillions of dollars repurchasing their own stock, almost all of it for the sole purpose of giving manipulative boosts to their companies' stock prices. Incentivizing these stock buybacks has been the stock-based pay of the senior corporate executives who make these buyback decisions. This legalized looting of the U.S business corporation dates back to the under-the-radar adoption of Rule 10b-18 in November 1982 by the Securities and Exchange Commission, as, under the Reagan administration, this U.S. federal agency turned from being a regulator to a promoter of stock-price manipulation. ${ }^{44}$ Increasingly, under a corrupt proxyvoting system, corporate raiders (aka hedge-fund activists), who simply buy and sell shares on the stock market, exert pressure on all-too-compliant corporate executives to downsize the labor force and distribute corporate cash to shareholders. ${ }^{45}$

These massive funds could have, and should have, been devoted to investment in upgrading the productive capabilities of American workers, both directly in the companies for which they worked and indirectly through taxes to fund investment in the nation's physical infrastructure and knowledge base that companies have needed to complement their own value-creating investments. It is reasonable to posit that if these investments in productive capabilities had been made over the past four decades, income distribution would be far more equitable and employment opportunity far more stable in the United States than they are now. As a result, the United States would probably have a growing and thriving middle class - one that could be, for example, much better prepared for and responsive to a pandemic. Through the dominance of a corporate regime for retain-and-reinvest resource allocation, the promise of equal employment opportunity would have been given a chance to succeed, with the probable result that socioeconomic divides by race, ethnicity, and gender would now be substantially reduced in the United States.

\footnotetext{
${ }^{42}$ See the articles and commentaries at "William Lazonick," Institute for New Economic Thinking, at https://www.ineteconomics.org/research/experts/wlazonick. See also the website of the Academic-Industry Research Network at http://www.theairnet.org/v3/.

${ }^{43}$ William Lazonick, "Congress can turn the Republican tax cuts into middle-class jobs," The Hill, February 7, 2018, at https://thehill.com/opinion/finance/372760-congress-can-turn-the-republican-tax-cuts-into-new-middle-classjobs; Lazonick, et al., "Why Stock Buybacks Are Dangerous for the Economy": William Lazonick, Matt Hopkins, Ken Jacobson, Lenore Palladino, Mustafa Erdem Sakinç, and Öner Tulum, "4 Ways to Eradicate the Corporate Disease That Is Worsening the Covid-19 Pandemic," Institute for New Economic Thinking Perspectives, March 23, 2020, at https://www.ineteconomics.org/perspectives/blog/4-ways-to-eradicate-the-corporate-disease-that-isworsening-the-covid-19-pandemic.

${ }^{44}$ Lazonick, "Stock Buybacks"; Lenore Palladino, "The \$1 Trillion Question: New Approaches to Regulating Stock Buybacks," Yale Journal of Regulation, 36, 2018: 89-105, at https://papers.ssrn.com/sol3/papers.cfm?abstract id=3274357; Ken Jacobson and William Lazonick, "A License to Loot: Opposing Views of Capital Formation and the Adoption of SEC Rule 10b-18," The Academic-Industry Research Network, forthcoming.

${ }^{45}$ Lazonick and Shin, Predatory Value Extraction, chs. 4-7.
} 
Instead, the MSV version of agency theory has provided academic justification for extreme economic inequality. This theory is rooted in a number of erroneous assumptions concerning the operation and performance of a modern economy:

- The agency theorists' notion that it is only shareholders who, as "principals," have a legitimate claim on the company's profits if and when they occur rests on the false assumption that it is only shareholders who take the risk of whether or not a company will be profitable.

- The agency theorists" notion that a company should "disgorge" its cash to shareholders is based on the false assumption that it is only shareholders who have made the investments that have enabled the company to generate profits.

- The agency theorists' notion that the "disgorged" cash is "free" assumes, incorrectly, that a company needs only to maintain its physical plant and equipment to remain profitable.

- The agency theorists' notion that through financial markets shareholders will reallocate the "disgorged" cash flow to its most efficient uses fails to analyze how, through investments in the productive capabilities of the labor force, these "most efficient uses" come into existence.

All of these false assumptions are rooted in what Lazonick has called "the myth of the market economy," based on the neoclassical fallacy, taught by $\mathrm{PhD}$ economists to millions upon millions of students, that the most unproductive firm is the foundation of the most efficient economy. ${ }^{46}$ Neoclassical economics, which provides the intellectual foundation for agency theory and MSV, lacks a theory of innovative enterprise and a theory of the developmental state. ${ }^{47}$ Here is what we know about the actual operation and performance of an economy that delivers stable and equitable growth:

- As a rule, public shareholders do not invest in a company's productive capabilities; they merely buy and sell shares that are outstanding on the market.

- As a rule, the function of the stock market has not been to fund investments in productive capabilities, but rather to separate share ownership from managerial control so that senior executives who have the abilities and incentives to invest in the firm's productive capabilities have the power to do so in ways that enable the company to generate high-quality, low-cost products.

- For a company to generate the high-quality, low-cost products that can generate profits on a sustainable basis, a substantial portion of those profits must be reinvested in productive capabilities that entail collective and cumulative learning by the company's labor force.

- Workers, whose skills and efforts enable the company to engage in collective and cumulative learning, as well as taxpayers, who fund government investment in infrastructure and knowledge that value-creating companies require, take risks that their investments may not

\footnotetext{
${ }^{46}$ William Lazonick, "Is the Most Unproductive Firm the Foundation of the Most Efficient Economy?: Penrosian Learning Confronts the Neoclassical Fallacy," Institute for New Economic Thinking Working Paper No.111, January 31, 2020, at https://www.ineteconomics.org/research/research-papers/is-the-most-unproductive-firm-thefoundation-of-the-most-efficient-economy-penrosian-learning-confronts-the-neoclassical-fallacy

${ }^{47}$ William Lazonick, Business Organization and the Myth of the Market Economy, Cambridge University Press, 1991; William Lazonick, "The Theory of the Market Economy and the Social Foundations of Innovative Enterprise," Economic and Industrial Democracy, 24, 1, 2003: 9-44; William Lazonick, "Innovative Enterprise or Sweatshop Economics? In Search of Foundations of Economic Analysis," Challenge, 59, 2, 2016: 65-114; Lazonick, "The Functions of the Stock Market"; Lazonick, "Is the Most Unproductive Firm the Foundation of the Most Efficient Economy?".
} 
generate corporate profits, and hence have a legitimate economic claim to shares of those profits via earnings and taxes if and when they occur.

- The economic roles of the developmental state are to invest in knowledge and infrastructure that business firms require to engage in innovation while preventing predatory value extraction - the appropriation of the gains from innovation by those actors in the economy who make the least contributions to generating those gains. ${ }^{48}$

From the perspective of the roles of the innovative enterprise and the developmental state in enabling stable and equitable economic growth, we argue that the business strategies and government policies required to reverse the plight of the American working class in general, and of the black working class in particular, must be rooted in a theory of the operation and performance of the economy that can explore rather than ignore the historical processes that enable the emergence and persistence of a strong middle class. Neither automation nor globalization laid waste to the American middle class. Automation and globalization have increased productivity, providing profits that can be invested in upgrading the labor force. The problem is that the financialization of the U.S. business corporation, facilitated by MSV ideology and a predatory state, has undermined the social processes of shared prosperity, within corporations and in the larger society of which they are a part. The reconstruction of the institutions for shared prosperity through government-business collaborations are essential for the existence and persistence of a strong middle class - and the survival of our economy and society.

\section{Documenting and analyzing "Fifty Years After"}

Given the particular focus of the "Fifty Years After" project on what has happened to the black middle class since the launching of the EEOC, we have analyzed a wealth of empirical evidence, including previously underutilized data collected by the EEOC, on the historical process of the emergence of a high-school-educated black middle class in the 1960s and 1970s and then the reversal of that process from the 1980s. The working papers to follow this introduction to our perspective document and analyze the socioeconomic failure of the United States in sustaining equal employment opportunity for African Americans, and ultimately for high-school-educated Americans more generally.

- "Employment and Earnings of Africa Americans, Fifty Years After: Progress?" provides a statistical picture of the current economic position of blacks, and the broad changes in the types of occupations that blacks have held in the U.S. economy from the post-World War II era to the present.

- "Employment Mobility and the Emergence of the Black Middle Class, 1890-1980" documents the ascendancy in the 1960s and 1970s of blacks to unionized blue-collar jobs as well as government employment that supported a middle-class standard of living.

- "The Unmaking of the Black Middle Class" analyzes when, how and why these middleclass employment opportunities for high-school-educated blacks disappeared, with downward socioeconomic mobility as a result.

- "Black Exclusion from High-Paid Employment in the New Economy" probes why collegeeducated blacks, as well as Hispanics, are so poorly represented, and Asian Americans so

\footnotetext{
${ }^{48}$ Lazonick and Shin, Predatory value Extraction.
} 
well represented, in STEM (science, technology, engineering, mathematics) employment, with a focus on leading information-and-communication technology (ICT) firms.

- "What Comes After Fifty Years After?" summarizes the policy implications of our research, including the need to embed these findings in a perspective that comprehends the types of organizations and institutions that support, and those that undermine, investments in the productive capabilities of a broad-based middle class and an equitable and stable distribution of the productivity growth that these capabilities make possible. 